\title{
Adequacy Analysis of Green Open Space and its Development Direction as an Attributes of Green City in the Capital of Jember Regency, Indonesia
}

\author{
* Santun R.P. Sitorus ${ }^{1)}$, Imelda Kusuma Wardani ${ }^{2)}$, and Setyardi Pratika Mulya ${ }^{2)}$
}

1) Department of Soil Science and Land Resources, Faculty of Agriculture, Bogor Agricultural University (IPB) Bogor. J1. Meranti Kampus IPB Bogor Indonesia 16680, Tel / fax: 0251-8422322

2) Land Resources Management Study Program, Department of Soil Science and Land Resources, Faculty of Agriculture, Bogor Agricultural University, Dramaga Campus IPB, Bogor Indonesia 16680.

$$
\text { Email: santun_rps@ipb.ac.id }
$$

*Corresponding Author, Received: February 17, 2018, Revised: April 25, 2018, Accepted: May 24, 2018

\begin{abstract}
The development of an urban area needs to pay attention to the environmental carrying capacity. One of the way to achieve sustainable urban development is to apply one of the attributes of green city namely green open space (GOS). The purpose of the research are to analyze the types of land use in the years of 2010 and 2017, to analysis land use changes from 2010 to 2017, predicting land use change, analyzing the adequacy of GOS by area acreage and population number, and to determine the direction of GOS development in the Jember City.The research was conducted in the Capital of Jember Regency, namely Jember City with the total area of 9,900 ha. Methods of data analysis are the spatial analysis, analysis of population growth with quadratic growth model, Cellular Automata-Markov, and synthesis of green open space (GOS) development direction based on potential land and the value of the land. The results showed that there are ten types of land use in the Jember City, those are forest, mixed gardens, dryland agriculture, open land, cemetery, plantation, settlements and buildings, paddy fields, shrubs and grasses, and river. A relatively large land use changed in the period of 20102017 were dryland agriculture and paddy fields into settlements and buildings. The results of land use prediction with Cellular Automata-Markov described the trend of land use change becomes settlements (buildings) and plantations. The adequacy of public GOS by area as well as population still lacking whereas the adequacy of private GOS has been exceeded. The GOS acreage based on number of population is lower than those GOS based on an area. The GOS development planning is required to fulfill the needs. The consideration used to draw up the directives is the existing land use, regional spatial plan (RTRW), prediction of land use in the year of 2024, distribution of GOS, and land values. Development plans of GOS consist of two stages namely stage 1 and stage 2 with three priorities, namely priority 1, priority 2, and priority 3 with the total area 1,052 ha and funding require approximately two trillion rupiahs. The acreage of potential land for development of GOS has already enough to fulfill the needs of GOS based on population, however, not yet sufficient to fulfill the needs of GOS based on regency area.
\end{abstract}

Keywords: Cellular Automata-Markov, Direction of GOS Development, Existing Land Use, GOS Acreage

\section{Introduction}

Spatial management in urban areas faces considerable challenges. The high level of urbanization in urban areas causes the urban population always increase. The increase in population also has implications for the existence of competition in land use. Development of urban areas should still pay attention to the 
environmental carrying capacity in order to reduce the negative environmental impact that can be experienced such as urban temperature increase and the existence of pollution. One alternative to resolving the issue in urban areas is to apply the concept of green city. GOS spatial planning is a part of city planning strategy to limit city development. Green City is an ideal picture of sustainable urban development. One of the green city attributes that became the focus of this research was the fulfillment of green open space (GOS).

Green open space is an elongated / lane and / or clumped area, whose use is more open, where plants grow, whether naturally grown or intentionally planted. GOS plays a role in sustainable urban development and city ecology that is able to provide economic, social and environmental benefits. The ecological benefits GOS one of which is to create a comfortable microclimate and reduce the effects of heat because of the vegetation (Buyadi et al., 2013; Hermon, 2014). Green open space (GOS) is able to provide space for human beings in performing social activities / needs, whether for sports, socializing with other human beings as well as other socio-cultural activities (Rukayah and Bharoto, 2012).

Based on Law Number 26 Year 2007 on Spatial Planning, the proportion of green open space is 30\% of the total area. Public green open spaces have a proportion of $20 \%$ of the total area and another $10 \%$ are open green private spaces. The adequacy of urban green space is still a problem in most urban areas. Research in GOS in several aspects had been carried out in many places. Among others are in Cimahi, West Java Province (Sitorus et al. 2013), in Bekasi, West Java Province (Sitorus et al. 2012a, Widiastuti 2012), in Ungaran City, Semarang District (Yunianto et al. 2016), in East Jakarta (Sitorus, 2012b), in South Jakarta (Sitorus et al. 2011) and in Jakarta City and Batu City (Rusadi et al. 2015; Hermon, 2017). All of them showed that public GOS are shortage, especially based on width of the area. One of the urban areas that have not met the standards set is Jember City. Jember City is the capital of Jember Regency, East Java. The city of Jember consisting of three sub-districts besides, is also a regional activity center (PKW) in Jember District. The green open space, especially the GOS public of Jember City, is not yet reached $20 \%$ of the area. Therefore, research is needed to identify the adequacy of green open space can then be formulated directives GOS development for the City of Jember toward green city.

Based on the background described above, the following research objectives are as follows: (1) Analyzing land use types in Jember City in 2010 and 2017, and land use change in 2010-2017, (2) Predicting land use change in Jember city in 2024, (3) To Analyze the adequacy of green open space based on the area and number of population in Jember city in 2017, and (4) To Arrange plan direction and estimate cost for development of green open space in Jember City.

\section{Method}

\section{Location and Time of Study}

The research was conducted in Jember Regency Capital City, Jember City, covering three districts namely Kaliwates, Patrang, and Sumbersari Subdistricts. The research was conducted during the period of November 2016 to July 2017. Data analysis was conducted in Studio of Regional Development Planning, Department of Soil Science and Land Resources, Faculty of Agriculture, IPB. The location of the study is presented in Figure 1. 


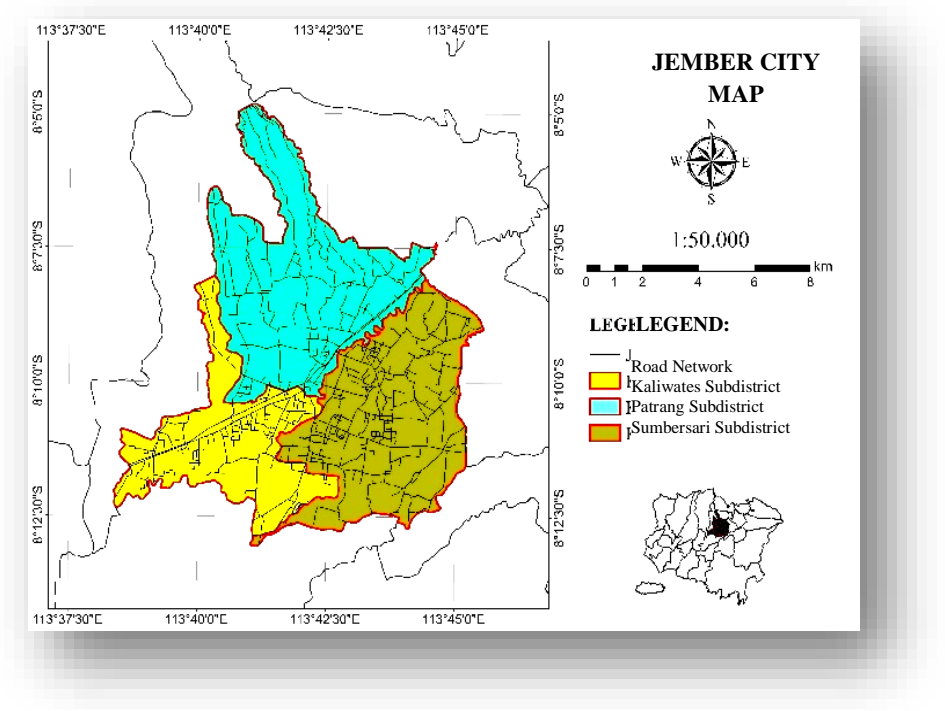

Figure 1. Location of study area

\section{Data Types, Data Sources and Research Tools}

Data type used in this research is primary data and secondary data. Primary data comes from direct observation, while secondary data comes from data obtained from several agencies. The primary data obtained from Google Earth and Quickbird to know types of land use in the city of Jember. In addition, the primary data in the form of land use in the actual conditions in the field is obtained through observations and field documentation and interviews to local residents and five stakeholders. Secondary data used Google Earth image 2016 from the Internet while the 2010 image obtained from the office of Agriculture Jember Regency in the form of Quickbird image. Map border administration Jember Regency, RTRW Map of Jember Regency, and Road Network Map obtained from Bappeda Jember District. Map of RBI obtained from the Geospatial Information Agency. The land value zone map is obtained from the National Land Agency of Jember Regency. In addition, quantitative data are also used, namely the population in Sumbersari, Patrang, and Kaliwates subdistrict from BPS Jember Regency and green open space data of Jember City in the form of tabulation data from the Office of Environment of Jember Regency. Spatial data in the form of maps all on a scale of 1: 50,000. The tools used in this study is a laptop that comes with the application of ArcGIS 10.3, 17.0 Idrisi (The Selva Edition), Microsoft Office, Statistica 7.0, AvenzaMaps, Universal Maps Downloader, and Google Earth Pro. Another tool used is the Global Positioning System (GPS), camera, field observation forms, and a list of structured questions.

\section{Data Collection and Data Analysis Techniques}

Secondary data were collected through literature studies and data collection from related agencies through a legal permit. Some of these agencies includes Geospatial Information Agency, Bappeda of Jember Regency, BPS of Jember Regency, Jember Regency Agricultural Service, Jember Regency Environmental Office, and National Land Agency of Jember Regency. Other data collected are primary data. Primary data collection is done by interpretation and image digitization, field observation, interview, and documentation of land use at each field observation point. Land use data and information and GOS distribution are obtained through image interpretation. The results of interpretation on the image updated with field observation data. Field observations were made at the points considered to represent each type of land use including green open space, unrecognizable objects, and some that experienced land use change. A total of 135 land use points (including 15 land use change points) and 26 GOS points observed in the field. If there is a difference between the interpretation result and the field observation result, it will be repaired again in accordance with the conditions in the field. In addition, interviews were conducted to local settlers (15 respondents) and five 
relevant stakeholders concerning GOS. Collected data then analysed. The description of the data analysis techniques used in the study is described below.

1. Interpretation, Digitizing images, and Spatial Analysis.

Image interpretation is an activity to determine the shape and nature of objects that appear on the image, including the description. Citra then digitized using ArcGIS 10.3 to get the boundaries of the object observed. Spatial analysis including geometric correction, overlay and geoprocessing.

2. Analysis Technique Cellular Automata-Markov (CA-Markov)

Land use maps of 2010 and 2017 are used as a basis to predict the land use in year of 2024. Land use map 2010 and 2017 converted to raster format with cell size 30 meters. Class of land use is encoded with an integer $(1,2,3$, etc.) with the Assign command. After that, the data is processed by Markov chain to make the probability of changes in land use. After that the simulation of land use in 2024 can be carried out with CA-Markov. According to Susilo (2011) Cellular Automata model is a dynamic model which can integrate spatial and time dimentions. Peruge et al. (2012); Hermon (2012), construct land use change model using Cellular Automata-Markov chain.

3. The calculation of green open space proportion to the total area and the population

The need for green space based on areage

The calculation of GOS of Jember City was conducted to find out whether GOS has fulfilled the minimum amount of GOS area based on the law. Green Open Space consists of public open space (20\%) and private GOS (10\%) of total area.

\section{GOS needs based on Population}

The calculation of the need for green open space based on the population is conducted by multiplying the population with the standard of green open space per capita. Green open space per capita needs in accordance with the Regulation of the Minister of Public Works No. 05 of 2008 was $20 \mathrm{~m}^{2}$ / capita.

\section{Technique of Growth Estimation}

Systematic growth estimates can be predicted from decay and growth functions. To determine the model of population growth, an analysis of the selection of the best growth model is a model which has a determinant coefficient $\left(\mathrm{R}^{2}\right)$ highest and the Standard Error (SE) the lowest.

4. Preparation of GOS development direction

The preparation of GOS development direction is done by synthesis of existing condition, adequacy of green open space, and potential area and value of land to be developed into GOS based on RTRW Jember Regency. After the location of GOS development is determined, the cost for the development of the green open space calculated using the land value. The results of the calculation of the cost of development of green open space is then adjusted to the budget available for the green open space so that the time needed to meet the needs of green open space.

\section{Results and Discussion}

\section{Land Use in 2010 and 2017 and Land Use Changes Year of 2010-2017.}

Land use is the result of a continuous human effort to meet its needs for available land resources (Sitorus 2017). Land use maps for 2010 and 2017 are presented in Figure 2. 


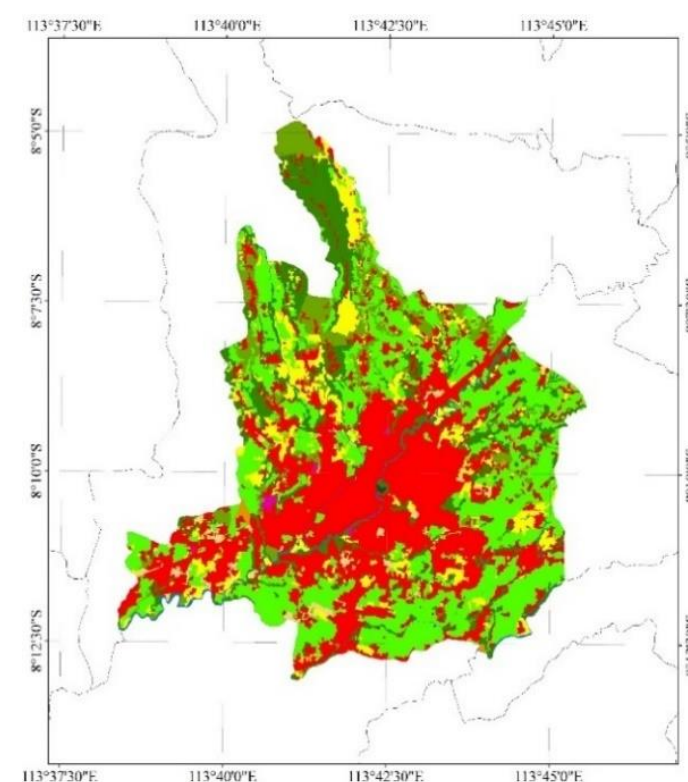

(a) 2010

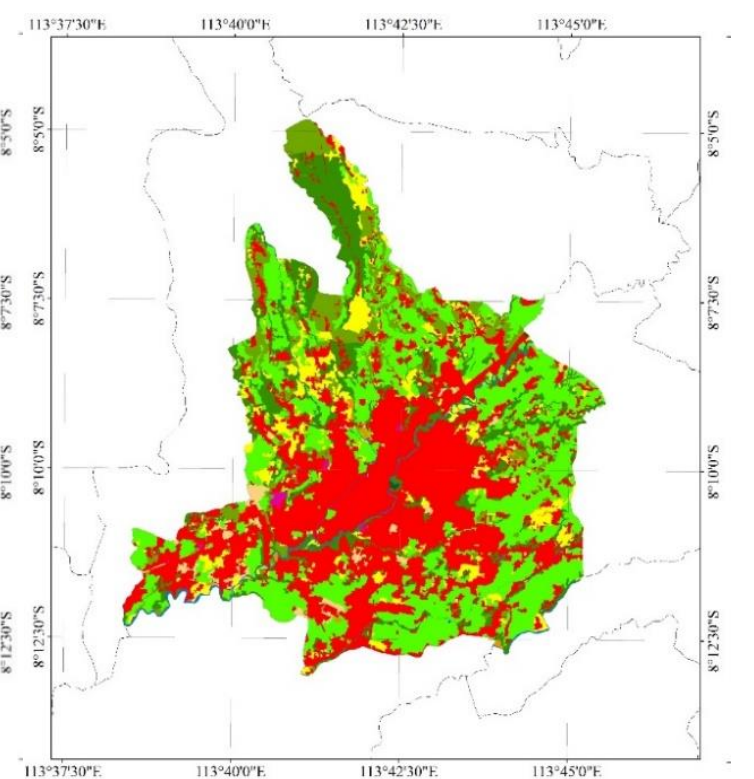

(b) 2017

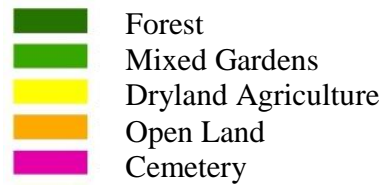

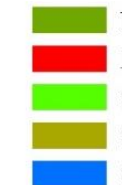

Plantations

Settlements and Buildings

Rice Fields

Shrubs and Grasses

Rivers

Figure 2. Land use maps for 2010 and 2017

Land use in Jember City in 2010 and 2017 consists of ten types, namely forests, mixed gardens, dry land agriculture, open land, cemetery, plantations, settlements and buildings, rice fields, shrubs and grasses, and river. The most widespread use of land in 2010 and 2017 are settlements and buildings and rice fields. In 2010, settlements and buildings accounted for approximately one third of the total area (3,495 ha). Similarly, the use of rice fields that also has an area of about $30 \%$ of the total area (3.222 ha). In 2017, the settlements and buildings contained in this city are $37 \%$ (3726 ha) while rice fields area of 3,091 ha or $31 \%$ of the total area. Land use in Jember City is still dominated by the use of agricultural land. This shows that although the city of Jember is an urban area, however, the city of Jember is still not very developed. In addition, mixed gardens are also a fairly extensive land use whereas forest is the most narrow land use $( \pm 5 \mathrm{ha})$. In the period of 2010-2017 there is a change of land use. The land use change map for 2010-2017, the 2010 and 2017 land use comparison charts, and the change matrix are shown in Figure 3, Figure 4, and Table 1, respectively. 
ISSN: 2580-4030 (Print) 2580-1775 (Online)

Vol 2, No. 1, (pp. 53-64), June, 2018

http://sjdgge.ppj.unp.ac.id

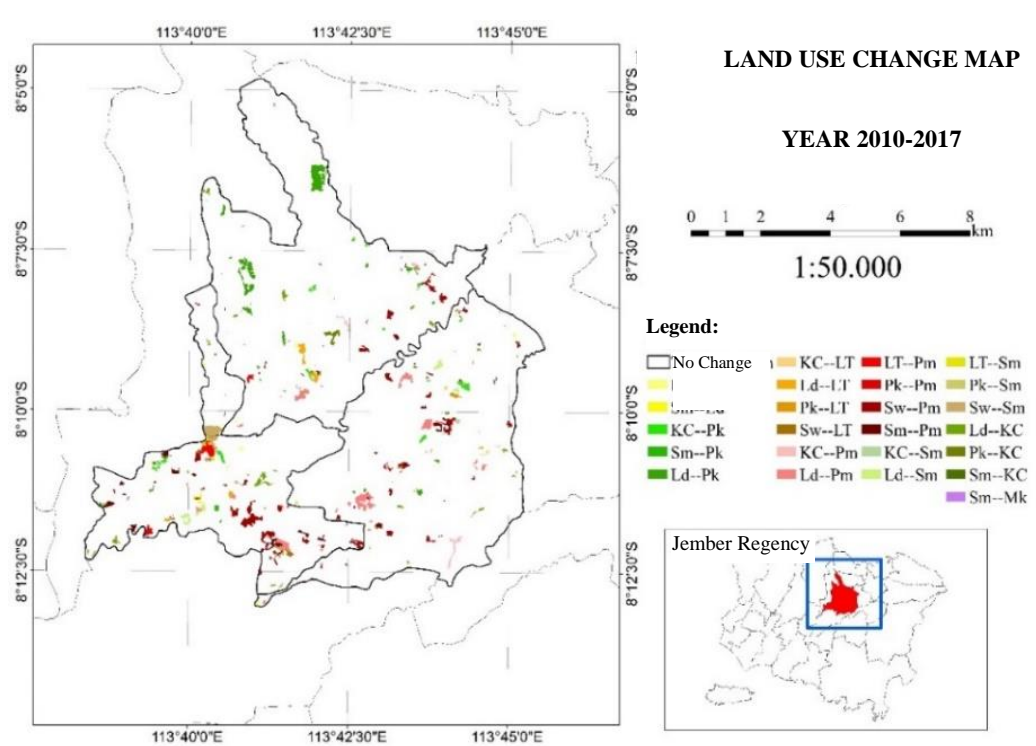

Explanation:

- $H t$ (Forest)

- KC (Mixed garden)

- Ld (dryland agriculture)

- LT (open land)

- $M k$ (cemetery)

- $P k$ (plantations)

- Pm (settlements and buildings)

- $S w$ (rice fields)

- Sm (Shrubs and grasses)

- $S g$ (River)

Figure 3. Land use change in 2010-2017

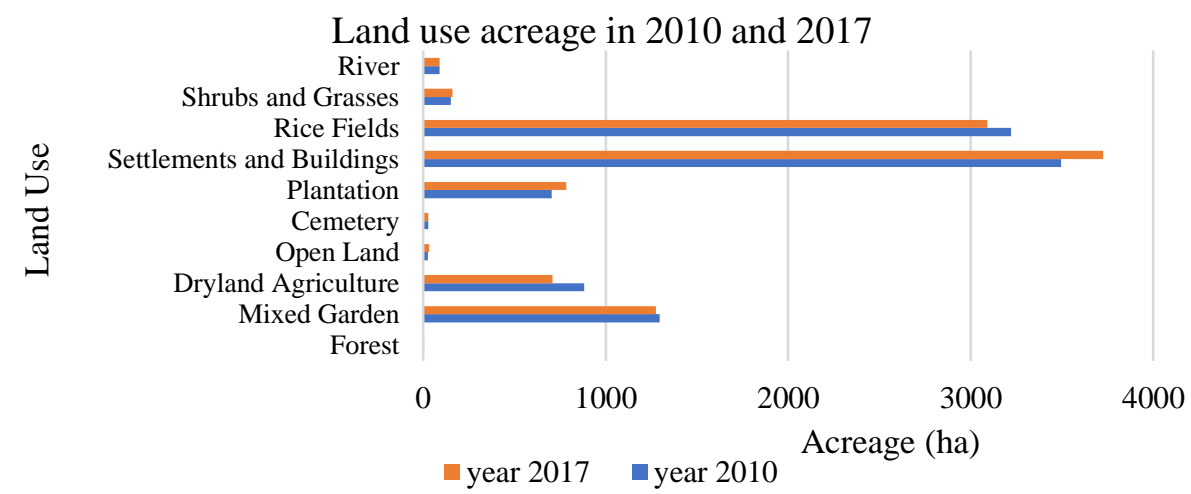

Figure 4. Comparison of land use area in 2010 and 2017

Table 1. Matrix of land use change 2010-2017

\begin{tabular}{|c|c|c|c|c|c|c|c|c|c|c|c|c|}
\hline \multirow{2}{*}{\multicolumn{2}{|c|}{ PL }} & \multicolumn{10}{|c|}{2017} & \multirow{2}{*}{ Total } \\
\hline & & $\mathrm{Ht}$ & $\mathrm{KC}$ & $\mathrm{Ld}$ & LT & $\mathrm{Mk}$ & $\mathrm{Pk}$ & $\mathrm{Pm}$ & $\mathrm{Sw}$ & $\mathrm{Sm}$ & $\overline{\mathrm{Sg}}$ & \\
\hline \multirow{10}{*}{2010} & $\mathrm{Ht}$ & & 0 & 0 & 0 & 0 & C & 0 & 0 & & 0 & 0 \\
\hline & $\mathrm{KC}$ & 0 & & 9.3 & 3.0 & 0 & 21.3 & 19.0 & 0 & 1. & 0 & 54.3 \\
\hline & $\mathrm{Ld}$ & 0 & 25.2 & & 15.1 & 0 & 72.3 & 58.6 & 0 & 15. & 0 & 187.1 \\
\hline & LT & 0 & 0 & 0 & & 0 & C & 13.9 & 0 & 4. & 0 & 17.9 \\
\hline & $\mathrm{Mk}$ & 0 & 0 & 0 & 0 & & C & 0 & 0 & & 0 & 0 \\
\hline & $\mathrm{Pk}$ & 0 & 6.8 & 0 & 2.8 & 0 & & 6.3 & 0 & 0. & 0 & 16.7 \\
\hline & $\mathrm{Pm}$ & 0 & 0 & 0 & 0 & 0 & C & & 0 & & 0 & 0 \\
\hline & Sw & 0 & 0 & 0 & 3.8 & 0 & C & 96.1 & & 30. & 0 & 130.3 \\
\hline & $\mathrm{Sm}$ & 0 & 0.3 & 3.0 & 0 & 0.6 & 2.4 & 37.6 & 0 & & 0 & 43.9 \\
\hline & $\mathrm{Sg}$ & 0 & 0 & 0 & 0 & 0 & C & 0 & 0 & & & 0 \\
\hline Total & & 0 & 32. & 12. & 24. & 0.6 & 9 & 231.5 & 0 & 52. & 0 & 450.2 \\
\hline
\end{tabular}


The total land use change is 450.2 ha. The changing land use observed in mixed gardens, dry land agriculture, open land, plantations, rice fields, as well as shrubs and grasses. The relatively broad change of land use is dry land agriculture (187.1 ha) which turns into other uses such as mixed gardens, open land, plantations, settlements, shrubs and grasses. In addition, the use of converted land in 2010-2017 is 130.3 ha of rice fields. Rice fields are transformed into settlements and buildings. Within the period of 2010 to 2017 it was identified that settlements and buildings was the most extensive added acreage (231,5 ha). Changes in land use to settlements and buildings were originally land that is classified as productive.

\section{Land Use Prediction Year 2024 with CA-Markov Method}

Land use prediction is related to two things: prediction of change area and prediction of location of change (Susilo 2011). The land use prediction map for 2024 is presented in Figure 5.

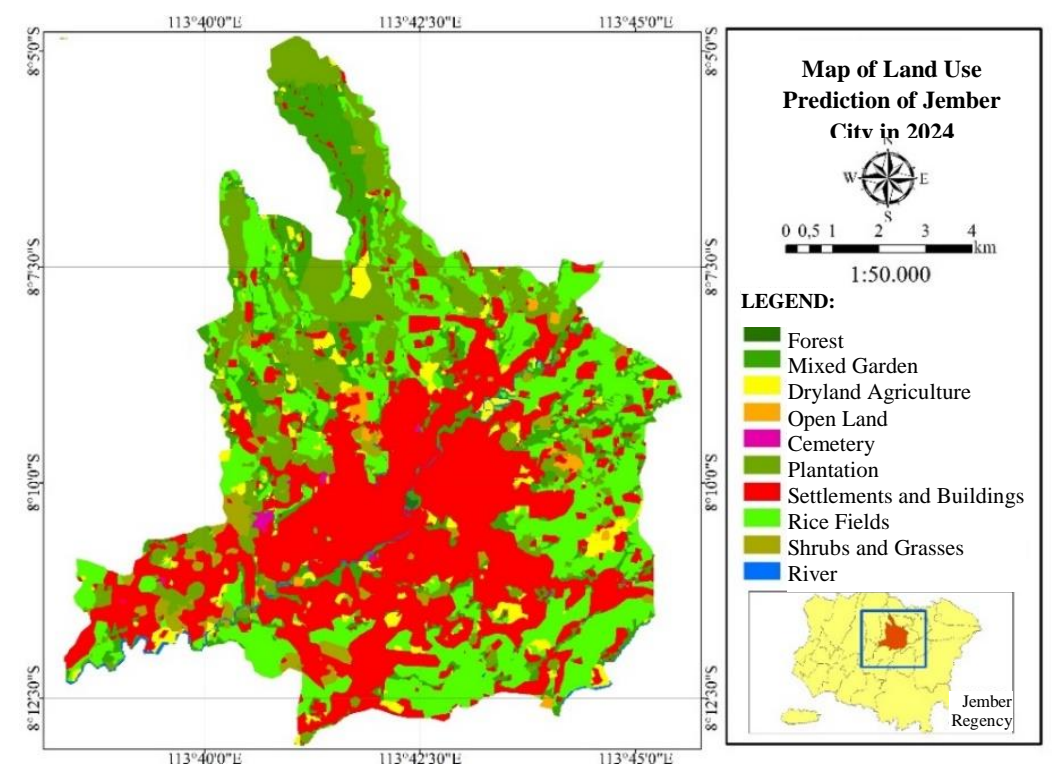

Figure 5. Map of land use prediction 2024

Table 2. Predicted land use in Jember city in 2024

\begin{tabular}{|c|c|c|}
\hline Land Use & Area (ha) & $\%$ \\
\hline Forest & 5 & 0.1 \\
\hline Mixed Gardens & 1.190 & 12 \\
\hline Dry Land Agriculture & 390 & 3.9 \\
\hline Open field & 76 & 0.8 \\
\hline Cemetary & 25 & 0.3 \\
\hline Plantation & 1.474 & 14.9 \\
\hline Settlements and Buildings & 3.857 & 38.9 \\
\hline Rice fields & 2,555 & 25.8 \\
\hline Shrubs and Grasses & 262 & 2.6 \\
\hline River & 66 & 0.7 \\
\hline Total & 9.900 & 100 \\
\hline
\end{tabular}

Land use predicted in 2024 indicates that the dominating lands are settlements and buildings, rice fields, plantations, and mixed gardens. The widespread use of plantation land and settlements and buildings is widespread, while the rice fields and dry land agriculture are narrowed. The use of settlements and buildings in 2024 is predicted to expand to $39 \%$ of the total area, whereas the use of ricefields decreases to $26 \%$ of the total area. The prediction of land use in 2024 also indicates the connection of rivers in Jember city or the area 
is decreasing. Reduced river area (disconnected) maybe occurs when processing and analyzing data by the application that is due to the change of vector format to raster or vice versa and neighborhood.

\section{Adequacy of Green Open Space by Area Acreage and Total Population}

The adequacy of green open space is calculated by the difference between the existing GOS and the need for green open space. The adequacy of green open space is analyzed by area acreage and population. The adequacy of green open space by area acreage is presented in Table 3.

Table 3. The need and adequacy of green open space by area acreage

\begin{tabular}{|c|c|c|c|c|c|c|c|}
\hline \multirow{3}{*}{ Sub.Districts } & \multirow{3}{*}{$\begin{array}{c}\text { Acreage } \\
\text { (ha) }\end{array}$} & \multicolumn{2}{|c|}{ GOS needs } & \multicolumn{2}{|c|}{ GOS Existing } & \multicolumn{2}{|c|}{ Adequacy of green open space } \\
\hline & & Public & Private & Public & Private & Public & Private \\
\hline & & \multicolumn{6}{|c|}{------ ha ------- } \\
\hline Kaliwates & 2,420 & 484 & 242 & 91.2 & $1,072.7$ & $-392.77(\mathrm{k})$ & $830.7(\mathrm{c})$ \\
\hline Patrang & 3.825 & 765 & 382.5 & 82.0 & $2,397.2$ & $-683(\mathrm{k})$ & $2,014,7$ (c) \\
\hline Sumbersari & 3.655 & 731 & 365.5 & 25.7 & $2,090.9$ & $-705,3(\mathrm{k})$ & $1,725.4(\mathrm{c})$ \\
\hline Total & 9.900 & 1.980 & 990 & 198,9 & $5,560.8$ & $-1.781 .1(\mathrm{k})$ & $4,570.8(\mathrm{c})$ \\
\hline
\end{tabular}

The width of green open space requirement based on the width of area of 1,980 ha (20\%) is public green open space and 990 ha $(10 \%)$ is private GOS. The green open space requirement from the most widespread are Patrang sub district (1,147,5 ha), Sumbersari (1,096,5 ha), and Kaliwates (726 ha), respectively. The adequacy of public open space in the three sub-districts is still very low. The inadequacy of public open space is highest in Sumbersari sub-district (-705.33 ha) and the total deficit of GOS in Jember city reaches 1.781,08 ha. Unlike the circumstances, the availability of private GOS has exceeded its needs. The adequacy of private GOS is a surplus of 4,570.78 ha. The need and adequacy of green open space based on population number is different from area acreage based. In Yogyakarta City according to Ratnasari et al. (2015), the acreage of GOS needed based on the width of area is 975 ha, and out of it, 612,17 ha GOS public. Data on the need and adequacy of green open space based on population numbers are presented in Table 4.

Table 4. The needs and adequacy of green space by population numbers

\begin{tabular}{l|c|r|r|r|r}
\hline \multirow{2}{*}{ Sub-districts } & \multirow{2}{*}{ Year } & \multirow{2}{*}{$\begin{array}{c}\text { Population } \\
\text { (capita) }\end{array}$} & GOS needs & Existing GOS * & GOS Adequacy * \\
\cline { 5 - 6 } & & \multicolumn{3}{c}{------ ha ------ } & $-153,8$ \\
\hline Kaliwates & 2017 & 122.503 & 245.0 & 91.2 & $-208,7$ \\
& 2024 & 149.982 & 299.9 & 91.2 & -328.0 \\
\multirow{3}{*}{ Patrang } & 2035 & 209606 & 419.2 & 91.2 & -118.0 \\
& 2017 & 100.004 & 200.0 & 82.0 & -143.1 \\
& 2024 & 112.539 & 225.1 & 82.0 & -197.2 \\
Sumbersari & 2035 & 139616 & 279.2 & 82.0 & -257.6 \\
& 2017 & 141.623 & 283.3 & 25.7 & -326.1 \\
& 2024 & 175.873 & 351.8 & 25.7 & -473.0 \\
\hline
\end{tabular}

Description: (*) GOS availability in 2024 and 2035 using the availability of green open space by 2017 due to unknown green open space in both years, (-) lack of green open space

The need for green open space based on population in 2017 in Kaliwates, Patrang, and Sumbersari sub-district are 245.0 ha; 200.0 ha; and 283.2 ha respectively. GOS needs until 2035 increased by $71 \%$ in Kaliwates Sub-District, 40\% in Patrang Sub-District, and 76\% Sumbersari. The availability of green open space in the city of Jember has not been able to meet the needs of green open space based on population. This deficit occurs in all three sub-districts. GOS 2017 state deficit of the greatest based on population occurred in the Sumbersari Sub-District (-257.6 ha). The width of existing green open space in Sumbersari sub-district is the least but in terms of population Sumbersari District is the most densely populated area. If the area of GOS in 
2024 and 2035 is assumed to be equal to the existing green open space in 2017, the shortage of green open space will be wider in 2024 and 2035.

\section{Plan and Cost Direction of GOS Development in Jember City Towards Green City}

Land use planning is essential to sustainable use of land resources intensively (Sitorus 2017). There are two considerations in drafting rational land use plan that is state land use right now (present land use) and potential land use (Sitorus, 2014). One form of land use planning in this study is the direction of GOS development. GOS development directives consider current land use, Jember District RTRW, GOS distribution, land use prediction in 2024, and land value zone. GOS development is preceded by land acquisition efforts. Potential land needs to be identified. Potentially land obtained from existing land use (2017). GOS development planning is prioritized on land use that has not or has not been used economically identified as open land, shrubs and grass, dryland agriculture, and mixed gardens. Potential land is then overlaid with the Regional Spatial Plan (RTRW) Jember that in the preparation of directives do not infringe the allocation of space in the RTRW. The direction of the GOS development plan and its extent is presented in Table 5.

Table 5. Distribution and extent of priority areas for GOS development

\begin{tabular}{lccrr}
\hline \multirow{2}{*}{ Priority } & \multicolumn{2}{c}{ Sub-District (ha) } & \multicolumn{2}{c}{ Total (ha) } \\
\cline { 2 - 5 } & Kaliwates & \multicolumn{2}{c}{ Patrang } & \multicolumn{2}{c}{ Sumbersari } & & \\
\hline 1-P1 & 18.8 & 5.9 & 12.4 & 37.1 \\
1-P3 & 12.9 & 2.2 & 7.9 & 23.0 \\
2-P1 & 59.1 & 169.8 & 62.9 & 291.8 \\
2-P2 & 0 & 85.3 & 0 & 85.3 \\
2-P3 & 88.1 & 340.1 & 186.5 & 614.7 \\
\hline TP & 248.7 & 544.9 & 329.9 & 1123.5 \\
\hline & Description: P1 (first priority), P2 (second priority), P3 (third priority), TP (not prioritized)
\end{tabular}

The direction of GOS development in this case related to land procurement is divided into two stages. The first phase begins with shrubs and grass and open land. The second stage is to allocate dryland agriculture and mixed gardens for green open space when shrubs and grasses and open land have not been able to meet the needs of public green open space. These two stages are subdivided into priorities. There are four priority classes that are synthesized: priority 1 , priority 2 , priority 3 , and not prioritized. Priority 1 is aimed at land within the spatial pattern as community forests as it is expected to become urban forest after being allocated to GOS. In addition, priority 1 is also synthesized from dryland agriculture. Priority 2 is rainfed rice fields, whereas priority 3 is land that in the pattern of space planned for plantation. Potential land for GOS development but not prioritized is land allocated for settlements and irrigated rice fields. Land in a spatial plan as vegetated land more easily converted to GOS than land for build up space. For example, the existing land in the form of open land means that the land is in phase 1 and the space pattern is allocated as community forest then it becomes a priority 1 , so it is encoded as 1-P1. FuGOSermore, the land planned for GOS development is the priority land $1(\mathrm{P} 1)$, priority $2(\mathrm{P} 2)$, and priority $3(\mathrm{P} 3)$.

Probable land acquisition is 1,052 ha. The land that can be prioritized in Patrang Subdistrict (603 ha) is wider than Sumbersari sub-district (270 ha) and Kaliwates sub-district (179 ha). The total area has not been able to meet the shortage of public green space in the city of Jember but has been able to meet the needs based on the number of population in 2017 and 2024. The progress of the development plan is done in stages, starting from the fulfillment of the needs of green open space based on the number of population in each sub-district and in the long term to achieve the adequacy of green open space by area acreage.

Stage and priority synthesis also needs to consider land use prediction results in 2024. Land use predictions provide an overview of the planned land for development of green open space to be transformed into a built area or not. The suitability of land use prediction in 2024 and RTRW of Jember City, especially those that are not appropriate according to the planned land for GOS development are presented in Table 6. 
Table 6. Conformity of land use prediction in 2024 with spatial plan of Jember City area according to land planned for GOS development

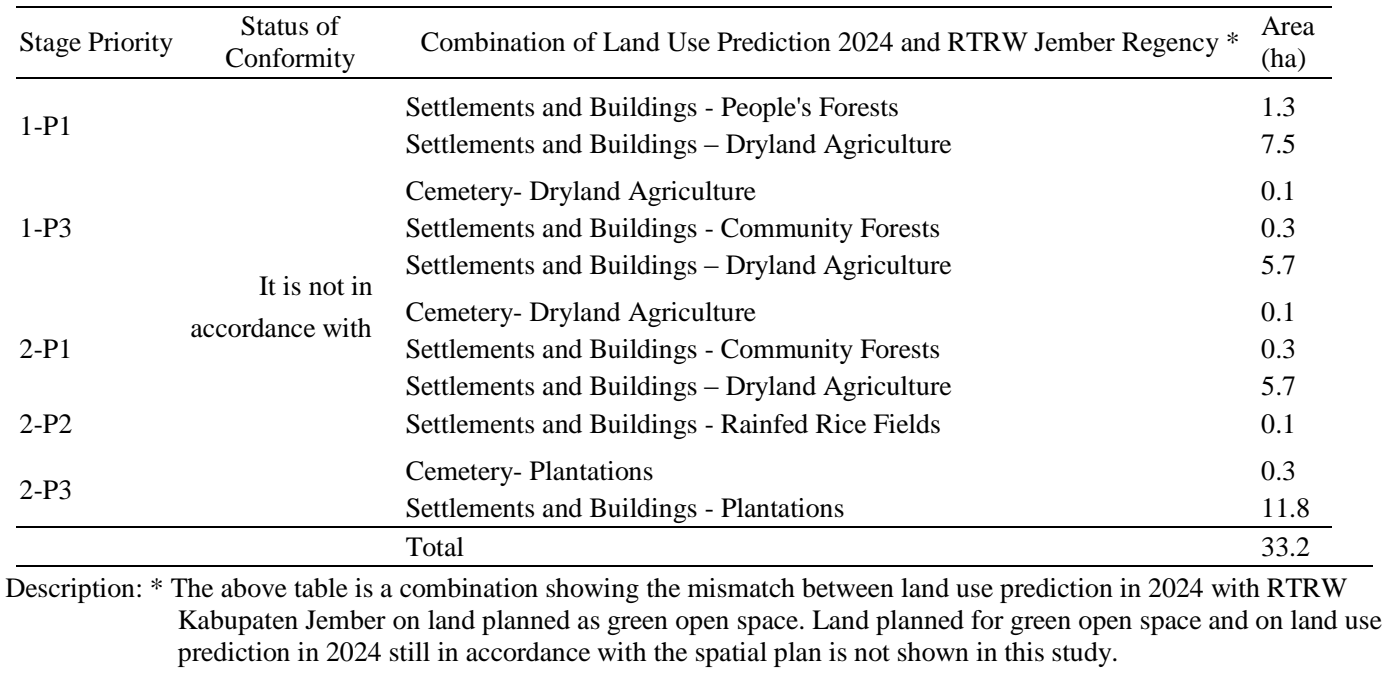

Land use prediction results in 2024 be overlaid with the direction of green open space development plan consisting of a potential land and spatial plan (RTRW). Land allocated to GOS as much as possible not to turn into built area. There are any land as Priority 1, priority 2, and priority 3 are converted to land based on predicted land use in 2024, which is 33.2 ha. It should be the government's attention in controlling the utilization of space so that the planned development of green open space that has been prepared can be done well. Public green open space development directives also consider the cost aspects. Costs are also taken into account to provide an overview of the funds that the government should allocate for GOS land procurement. The cost of land acquisition is based on the value of land and budget allocated by the government for the development of green open space. Land that has a low value (Rp. 100,000/ $\mathrm{m}^{2}$ ) are preferred in the plan implementation. The cost needed to increase public open space to be $13 \%$ (1,052 ha) approximately 2 trillion rupiah. The cost is the cost for land procurement, not including the cost of developing green open space. If the annual budget for the procurement of green open space is currently 500 million rupiah then the procurement of land for the development of green open space is planned to take 3,991 years. This becomes impossible if the policy in budgeting remains as it is today. To overcome the problem of the availability of funds in related institutions that are too small, there are four alternative sources of financing that can be considered, namely:

1. The government needs to increase the allocation of funds for the procurement of GOS land each year. The current allocation of funds is only 500 million rupiah need to be added so that the time to meet the needs of green space is not too long.

2. The government can use the land assets of Jember goverment. Jember Regional Government owns land assets in various types of land use. The government needs to identify appropriate local government land and be available for the development of green open space so that the costs required for procurement of green space can be reduced.

3. The government can partner with various parties to develop the GOS. The realization of the adequacy of public open space can be done by all parties and stakeholders. Partnership is one way to meet the needs of green space. This partnership can be done by the private sector, for example in the form of Corporate Social Responsibility (CSR).

4. The government cooperated with the developer. The government should require developers to allocate land to be used as green open space, and given to the government of Jember.

5. The things mentioned above is an attempt to meet the needs of Jember City GOS so as to fulfill one of the attributes of green city. 


\section{Conclusion}

Based on the above description and result, several conclusions can be drawn as follows: (1) Land use types in Jember City include forests, mixed gardens, dryland agriculture, open land, cemetery, plantations, settlements and buildings, rice fields, shrubs and grasses, and rivers. The relatively large land use changes are rice fields and dryland agriculture, while the majority of land use is transformed into settlements and buildings, (2) The prediction results of land use in 2024 can be described using the CA-Markov method. The use of predicted land shows that the area of settlements and buildings and plantations that are increasingly widespread, while the rice fields and dryland agriculture are getting narrower. The most widespread use of land based on predictions are settlements and buildings, rice fields, plantations, and mixed gardens, respectively, (3) Existing acreage of public green space is still lacking, either based on by area (-1781.1 ha) or based on the number of population (- $529.3 \mathrm{ha}$ ). The largest shortage of public green open space area in the Sumbersari sub-District ($705.3 \mathrm{ha}$ ). The area of private green open space has exceeded its needs, and (4) The direction of development of public green space is done in two stages with the three priorities, namely P1, P2, and P3 with a total area of 1,052 ha and will cost approximately 2 trillion rupiah. The area of land planned for the development of green open space has been able to meet the needs of the GOS based on the population but the need for green open space by area acreage is still not fulfilled. Suggestions that can be given are: (1) Land acquisition for the development of public green open space is recommended gradually, taking into account the adequacy of green open space based on population. GOS adequacy based on an area suggested to be used as a fulfillment of longterm outcomes, (2) Development direction of public green open space should be added into the planning of green open space in the city of Jember, and (3) Allocation of funds for land acquisition of a public green open space suggested should be increased so as to facilitate efforts to develop green open space in the city of Jember.

\section{References}

Buyadi SNA, Mohd WMNW, Misni A. (2013). Green spaces growth impact on the urban microclimate. Procedia-Social and Behavioral Sciences. 105: 547-557.

[DPU] Department of Public Works, Directorate General of Spatial Planning. (2007). Law No. 26 Year 2007 on Spatial Planning in Indonesian. (In Indonesian).Jakarta (ID): Department of Public Works, Directorate General of Spatial Planning.

Hermon, D. (2012). Mitigasi Bencana Hidrometeorologi: Banjir, Longsor, Degradasi Lahan, Ekologi, Kekeringan, dan Puting Beliung. UNP Press.

Hermon, D. (2014). Geografi Bencana Alam. Radjawali Press.

Hermon, D. (2017). Climate Change Mitigation. Radjawali Press (Radjagrafindo). Jakarta.

Ministry of Public Works. (2008). Regulation of the Minister of Public Works No. 5 of 2008 regarding Guidelines for Provision and Use of Green Open Space in Urban Area (In Indonesian) . Jakarta (ID): Ministry of Public Works.

Peruge TVG, Arief S, Sakka. (2012). Land Use Convertion Model Using cellular automata- markov chain in Mamminasata Region (In Indonesian). Majalah Geografi Indonesia. 25 (1): 41-49.

Rahmy WA, Faisal B, Soerijaatmadja AR. (2012). City green open space needs in densely area. Case study in Tegallega region, Bandung (In Indonesian). Jurnal Lingkungan Binaan Indonesia. 1 (1): 27-38.

Ratnasari A, Sitorus SRP, Tjahjono B. (2015). Green City Planning of Yogyakarta based on land use and green open space fulfillment (In Indonesian). Tata Loka. 17 (4): 196-208.

Rukayah S, Bharoto. (2012). Bazaar in urban open space as contain and containercase study: Old Town Square and Simpang Lima Semarang, Central Java, Indonesia. Procedia-Social and Behavioral Sciences . 50: 741-755.

Rusadi EY, Nurhayati P, Tallo AJ, Setiawan B. (2015). Smart green open space outlook: pattern identification (case study: Yogyakarta City and Batu City) (In Indonesian). Procedia-Social and Behavioral Sciences. 227: 630-636. 
Sitorus SRP, Ashri M, Panuju DR. (2013). An Analysis of green open space availability and Regional Development hierarchy in Cimahi City, West Java Province (In Indonesian). Jurnal Tanah dan Lingkungan. 15 (2): 66-75.

Sitorus SRP, Leonataris C, Panuju DR. (2012a). An Analysis of Land Use Change Pattern and Regional Development in Bekasi City, West Java Province. (In Indonesian). Jurnal Tanah dan Lingkungan. 14 (1): 21-28.

Sitorus SRP, Patria SID, Panuju DR. (2012b). An Analysis of Green Open Space Land Use in East Jakarta (In Indonesian). Jurnal Lanskap Indonesia. 4 (2): 28-36.

Sitorus S.R.P, Aurelia W, Panuju D.R. (2011). An Analysis of Green Open Space Acreage Change and Factors affecting it in South Jakarta. (In Indonesian). Jurnal Lanskap Indonesia 2(1): 5-20.

Sitorus SRP. (2014). Development of Sustainable Land Resources (In Indonesian) . Bogor (ID): Department of Soil Science and Sumberdaya Lahan, Faculty of Agriculture, IPB.

Sitorus SRP. (2017). Land Use Planning (In Indonesian) . Bogor (ID): IPB Press.

Susilo B. (2011). Probabilistic modeling of spatial integration markov chain and cellular automata to study regional scale changes in land use in the province of Yogyakarta Special Region. (In Indonesian) Gea. 11 (2): 163-178.

Yunianto AD, Sitorus SRP, Munibah K. (2016). An Analysis and Green Open Space Development Direction in Supporting Green City of Ungaran City,Semarang District. (In Indonesian). Kawistara. 6 (1): 1-9. 